\title{
PENGARUH PEMBERIAN AROMA TERAPI ROSE DAN AKUPRESUR PADA IBU MENYUSUI PASCA SAESAR CAESAREA TERHADAP KECUKUPAN ASI PADA BAYI
}

\author{
Fepi Susilawati*, Abdul Halim* \\ *Jurusan Keperawatan Poltekkes Tanjungkarang \\ E-mail: Fepi05susilawati@gmail.com
}

\begin{abstract}
Proses melahirkan Seccio Caesarrea (SC) menyisakan nyeri, cemas dan lain-lain yang dapat menghambat produksi ASI. Aalah satu upaya untuk memperlancar produksi ASI adalah dengan melakukan aroma therapi dan akupresur selain memberikan makanan bergizi. Aroma terapi dan akupresur dapat meningkatkan produksi ASI yaitu meningkatkan produksi oksitocin yang dilakukan dengan cara pemijatan pada titik tertentu. Tujuan penelitian untuk mengetahui pengaruh relaksasi aroma terapi rose dan akupressur pada ibu menyusui pasca SC terhadap kecukupan ASI bayi usia 1-3 hari yang dirawat di RSD May jend H.M Ryacudu Kotabumi tahun 2017. Jenis penelitian quasi eksperiment, desain one group time series . Populasinya seluruh ibu menyusui pasca SC, Sampel berjumlah 105 orang dengan tehnik incidental dan quota sampling. Uji statistiknya partial dalam analisis regresi (Uji F/Anova). Hasilnya adalah ada pengaruh aroma terapi rose dan akupressur pada ibu menyusui pasca SC terhadap kecukupan ASI bayi umur1-3 hari, derajad kepercayaan 0.05 didapat nilai $\alpha 0.00<0.05$ dan $\mathrm{R}$ Square berbeda-beda pada titik akupressur (46,8 di tangan), (38,0 di kaki), 79,8 (leher dan punggung) serta 100 pada tangan, kaki, leher dan punggung. Sarannya hendaklah hasil penelitian dapat diaplikasikan dalam bentuk pemberian tindakan keperawatan sehingga bisa meningkatkan kualitas pelayanan keperawatan terutama pada perawat komunitas dan praktek mandiri keperawatan.
\end{abstract}

Kata kunci: Aroma terapi rose dan akupressur, ibu post SC, Kecukupan ASI

\section{LATAR BELAKANG}

Pada anak ada beberapa masalah yang juga beresiko pada kematian, seperti perdarahan pada ibu, penyakit infeksi, faktor pemberian ASI dan sebagainya. Berdasarkan data WHO tahun 2012 di 6 negara berkembang yaitu bayi berusia 9-12 bulan yang tidak disusui akan beresiko mengalami kematian sebesar $40 \%$. Angka ini akan meningkat menjadi $48 \%$ pada bayi kurang dari 2 bulan yang tidak mendapatkan air susu ibu (ASI) seperti pernyataan Utami Roesli dalam Astuti (2015), dengan demikian ada jutaan bayi yang dapat terselamatkan dengan ASI yaitu dengan pemberian air susu ibu (Kemenkes RI, 2015)

Astuti (2015) menyatakan bahwa pemberian ASI menyelamatkan sekitar 1,5 juta bayi pertahun dari kesakitan dan kematian. Pemberian ASI di Indonesia Berdasarkan hasil analisis Riset Kesehatan
Dasar (Riskesdas) tahun 2010 ada 15,3\% bayi yang menyusu ekslusif sampai enam bulan, Presentase menyusui dini kurang dari 1 jam setelah lahir ada 29,3\%, presentase menyusui bayi setelah 48 jam sebesar $11,1 \%$, serta presentase pemberian kolostrum oleh ibu kepada bayinya cukup baik yaitu $74,7 \%$.

Provinsi Lampung tahun 2014, jumlah bayi yang diberi ASI ekslusif sebesar 67.260 bayi atau $41,13 \%$ dari total bayi sebesar 163.546 orang, Untuk Kabupaten Lampung Utara ada 2.404 atau 40,7\% dari total bayi 5.907 bayi (Dinkes Prop Lampung, 2015).

ASI merupakan makanan tunggal dan terbaik yang memenuhi semua kebutuhan tumbuh kembang bayi sampai usia 6 bulan, untuk menambah kuantitas dan kualitas Asi ada berbagai cara yang bisa dilakukan seperti makanan makanan bergizi, senam, akupresur dan sebagainya. (Astuti, 2015). 
Relaksasi aroma terapi rose merupakan pengobatan alternative tradisional yang dapat membangkitkan efek relak pada ibu yang habis melakukan operasi SC dari rasa kesakitan karena mengandung berbagai kandungan seperti minyak atsiri salah satunya adalah mengandung asam aspartat yang berfungsi sebagai vasodilator pembuluh darah dan asam askorbat yang akan merangsang produksi hormon seperti hormone prolaktin. Akupresur adalah teknik pemijatan (penekanan) menggunakan metode perangsangan pada titik akupuntur sehingga dapat meningkatkan oksitosin yang diperlukan tubuh untuk merangsang pengeluaran ASI (Sukanta, 2014). Hasil penelitian Vidayanti (2015) dengan melakukan pijat punggung menggunakan Minyak Esensial Lavender terhadap Produksi ASI mendapatkan hasil adanya perbedaan kelancaran produksi ASI antara kelompok pijat menggunakan minyak esensial lavender dan kelompok kontrol dengan $p$-value 0,007 dan OR sebesar 4,84 (65\% CI : 1,68-13,93).

Hasil prasurvei yang telah dilakukan di rumah sakit yang bukan merupakan lokasi penelitian terhadap $30 \mathrm{ibu}$ post sectio caesarea (SC) yang melahirkan di RS Mutiara Bunda bulan Februari 2017, yang memberikan ASI sebanyak 10 Ibu (33,3\%), terbanyak ibu (6 orang) yang mengatakan produksi ASI pada dirinya kadang keluar dan kadang tidak pada minggu pertama melahirkan post SC, hal ini bisa disebabkan karena ada rasa trauma karena melahirkan dengan operasi SC, sedangkan hasil wawancara terhadap bidan yang merawat ibu setelah melahirkan didapatkan hasil bahwa lebih banyak ibu yang setelah SC mengalami kekurangan produksi ASI dibandingkan dengan yang melahirkan normal yaitu dari 52 ibu yang melahirkan, post SC (30 orang) dan melahirkan normal (22 orang), dari mereka diperoleh data 27 orang (52\%) post SC mengalami produksi ASI kurang sehingga harus diganti dengan PASI. Kenyataan dan kondisi yang dialami oleh pasien secara objektif seperti ini belum mendapat perhatian dari perawat, padahal kondisi ini sangat memerlukan peran aktif perawat yaitu peran pada tindakan keperawatan secara mandiri dengan menerapkan ilmu dan ketrampilan komplementer yang dapat berkembang menjadi bentuk kegiatan enterpreneurship bagi perawat, bila dikembangkan di dalam komunitas.

\section{METODE}

Jenis penelitian ini adalah quasi eksperimen karena subjek tidak dilakukan secara random, tetapi dengan kelompok yang sudah tersedia. Desain penelitian one group time series design. Populasi penelitian adalah seluruh ibu menyusui pasca SC dengan sampel berjumlah 105 orang yang diambil dengan tehnik incidental dan quota sampling. Penelitian ini melakukan pengamatan terhadap pengaruh ketika kondisi tersebut dimanipulasi yaitu manipulasi dilakukan terhadap variable bebas dan pengaruhnya diamati pada variable terikat.

Data penelitian akan dianalisis secara univariat menggunakan distribusi frekwensi dan bivariat dengan uji regresi linear ganda partial (Uji F / uji anova), dengan tingkat kepercayaan $95 \%$ menggunakan bantuan komputer.

\section{HASIL}

\section{Analisis Univariat}

Tabel 1: Distribusi Responden Berdasarkan Aroma Therapi Rose dan Titik Akupresur

\begin{tabular}{lcc}
\hline Aroma Terapi \& Titik Akupresur & $\mathrm{f}$ & $\%$ \\
\hline $\begin{array}{l}\text { Aroma terapi rose \& akupresur } \\
\text { di Tangan }\end{array}$ & 24 & 23 \\
\hline $\begin{array}{l}\text { Aroma terapi rose \& akupresur } \\
\text { di kaki }\end{array}$ & 26 & 25 \\
\hline $\begin{array}{l}\text { Aroma terapi rose \& akupresur } \\
\text { di leher, punggung }\end{array}$ & 26 & 25 \\
\hline $\begin{array}{l}\text { Aroma terapi rose \& } \\
\text { akupresur di tangan, kaki, } \\
\text { leher, punggung }\end{array}$ & 29 & 27 \\
\hline \multicolumn{1}{c}{ Jumlah } & 105 & 100 \\
\hline
\end{tabular}


Pasien yang berpartisipasi dalam penelitian dan aktif menjadi responden penelitian yang dilakukan dalam waktu 3 hari, terdistribusi merata pada 4 (empat) area titik akupressur .

Tabel 2: Distribusi Kelancaran ASI Pada Ibu Menyusui Pasca SC Berdasarkan Titik Akupresur 1-3 Hari

\begin{tabular}{lcccccccccccc}
\hline \multirow{2}{*}{$\begin{array}{l}\text { Titik } \\
\text { Akupresur }\end{array}$} & \multicolumn{10}{c}{ Hari Pertama } & \multicolumn{10}{c}{ Hari Kedua } & \multicolumn{1}{c}{ Hari Ketiga } \\
\cline { 2 - 13 } & Tdk $\%$ & Ya & $\%$ & Tdk & $\%$ & Ya & $\%$ & Tdk & $\%$ & Ya & $\%$ \\
\hline Di Tangan & 24 & 100 & 0 & 0 & 8 & 33 & 16 & 67 & 8 & 33 & 16 & 67 \\
\hline Di kaki & 26 & 100 & 0 & 0 & 24 & 92 & 2 & 8 & 10 & 38 & 16 & 62 \\
\hline $\begin{array}{l}\text { Di Leher \& } \\
\text { Punggung }\end{array}$ & 23 & 88 & 3 & 12 & 10 & 38 & 16 & 62 & 4 & 15 & 22 & 85 \\
\hline $\begin{array}{l}\text { Di Tangan, } \\
\text { Kaki, Leher } \\
\text { \& Punggung }\end{array}$ & 25 & 86 & 4 & 14 & 9 & 31 & 20 & 69 & 6 & 20 & 23 & 80 \\
\hline
\end{tabular}

Tabel di atas menggambarkan bahwa pada 4 (empat) titik akupresur yang diteliti, hari pertama produksi ASI belum ada, yang ada hanya pengeluaran kolostrum, kemudian pada hari ke-2 (dua) produksi ASI sudah mulai lancar dan terjadi peningkatan pada hari ke-3 (tiga).

Tabel 3: Distribusi Kecukupan ASI pada Bayi Umur Berdasarkan Titik Akupresur 1-3 Hari

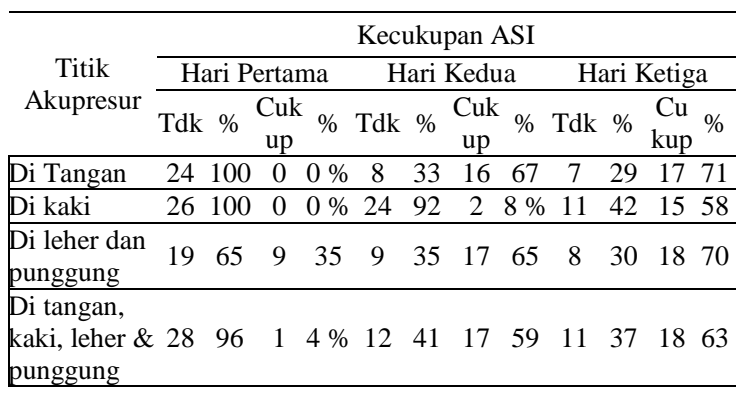

Tabel di atas menjelaskan bahwa kecukupan ASI pada bayi umur 1-3 hari, semakin meningkat pada hari ke-3 (tiga). Pada Hari pertama tampak belum tercukupi pemenuhan kebutuhan ASI kemudian semakin meningkat dari hari ke hari hingga hari ketiga, namun kecukupan ASI ini bervariasi karena faktor pengaruh dari ibu.
Tabel 4: Distribusi Produksi ASI dan Kecukupan ASI Berdasarkan Titik Akupresur

\begin{tabular}{lcccccccc}
\hline \multirow{3}{*}{ Titik Akupresur } & \multicolumn{3}{c}{ Produksi ASI } & \multicolumn{3}{c}{ Kecukupan ASI } \\
\cline { 2 - 9 } & \multicolumn{2}{c}{ Lancar } & \multicolumn{2}{c}{ Tidak } & \multicolumn{2}{c}{ Cukup } & \multicolumn{2}{c}{ Tidak } \\
\cline { 2 - 9 } & $\mathrm{f}$ & $\%$ & $\mathrm{f}$ & $\%$ & $\mathrm{f}$ & $\%$ & $\mathrm{f}$ & $\%$ \\
\hline Di Tangan & 16 & 60 & 8 & 40 & 16 & 60 & 8 & 40 \\
\hline Di kaki & 6 & 23 & 20 & 77 & 4 & 15 & 22 & 85 \\
\hline Di Leher dan Punggung & 18 & 69 & 8 & 31 & 16 & 61 & 10 & 39 \\
\hline Di Leher dan Punggung & 19 & 65 & 10 & 35 & 16 & 55 & 13 & 45 \\
\hline Jumlah & 59 & - & 46 & - & 52 & - & 53 & \\
\hline
\end{tabular}

Pada tabel di atas tergambar prosentase terbesar ketidaklancaran produksi ASI dan ketidak cukupan ASI berada pada area titik akupressur di kaki.

\section{Analisis Bivariat}

Tabel 5: Dsistriusi Pengaruh Aroma Terapi Rose dan Akupressur pada Ibu Menyusui Pasca SC Terhadap Kecukupan ASI Bayi

\begin{tabular}{|c|c|c|c|c|}
\hline $\begin{array}{l}\text { Variabel } \\
\text { Penelitian }\end{array}$ & F tabel & $\begin{array}{c}\mathrm{F} \\
\text { hitung }\end{array}$ & Sig & $\begin{array}{c}\mathrm{R} \\
\text { Square }\end{array}$ \\
\hline Di Tangan & 3.4 & 22.0 & 0.00 & $46,8.0$ \\
\hline Di kaki & .4 & 15.0 & 0.00 & 38,0 \\
\hline $\begin{array}{l}\text { Di Leher dan } \\
\text { Punggung }\end{array}$ & 3.4 & 64 & 0.00 & 79.8 \\
\hline $\begin{array}{l}\text { i Leher da } \\
\text { unggung }\end{array}$ & 3.3 & 27 & 0.00 & 100 \\
\hline
\end{tabular}

Membaca tabel yang tersaji di atas dari hasil penelitian diketahui bahwa relaksasi aroma rose dan akupressur mempunyai pengaruh yang sama terhadap produksi ASI ibu menyusui pasca SC, hasil uji statistic menunjukkan nilai signifikansi $0.00(0.00<0.05)$ yang dilihat dengan derajad kepercayaan $95 \%$ dan nilai $F$ tabel $<F$ hitung.

Pada berbagai variabel penelitian diketahui besarnya prosentase mempengaruhi hasil berbeda-beda: Relaksasi aroma terapi rose dan akupressur di tangan $46.8 \%$ secara bersama-sama mempengaruhi produksi ASI. Relaksasi aroma terapi rose dan akupressur di kaki 38 \% secara bersamasama mempengaruhi produksi ASI. Relaksasi aroma terapi rose dan akupressur di leher dan punggung $79.8 \%$ secara 
bersama-sama mempengaruhi produksi ASI. Relaksasi aroma terapi rose dan akupressur di tangan, kaki, leher dan punggung $100 \%$ secara bersama-sama mempengaruhi produksi ASI

Hasil penelitian di atas menunjukkan bahwa Ha penelitian diterima yaitu ada pengaruh relaksasi aroma terapi rose dan akupressur pada ibu menyusui pasca SC terhadap kecukupan ASI bayi umur 1-3 hari.

\section{PEMBAHASAN}

\section{Relaksasi Aroma Terapi Rose}

Mulai hari pertama terdapat rasa nyaman dan ada sensasi (rasa) aliran pada payudara (vasodilatasi pembuluh darah dan rangsangan pada kelenjar alveoli payudara), walaupun ASI yang keluar hanya colostrum. Hal ini sesuai dengan pernyataan Astuti (2015) bahwa pengeluaran ASI belum terjadi pada minggu pertama.

Hari ke-2 (dua) terjadi peningkatan kelancaran ASI antara $8 \%-38 \%$ dan semakin meningkat pada hari ke-3 (tiga), peningkatan kelancaran ASI pada hari ke-3 (tiga) antara $34 \%-70 \%$. Hal ini disebabkan: a) Keterpaparan ibu terhadap aroma terapi rose semakin sering sehingga membuat ibu semakin merasa nyaman karena kandungan asam tartat (aspartat) pada rose, asam aspartat akan merangsang sel-sel syaraf, bersifat menyegarkan; b) Kondisi kesehatan ibu semakin hari semakin meningkat, setelah pemulihan masa operasi (hari ke-3 merupakan masa pemulangan).

Sebab di atas mendukung pernyataan Muchtaridi (2015) yang menyatakan bahwa salah satu efek aroma terapi adalah efek farmakologis nya mengatasi depresi dan cemas, sedangkan Blogspot.co.id (2016) menyatakan bahwa kandungan asam tartat (aspartat) pada rose bersifat merangsang saraf, menyegarkan dan meningkatkan gairah hidup sehingga terjadi perasaan relaks dan nyaman. Astuti (2015) menyatakan bahwa kesehatan fisik akan mempengaruhi produksi ASI.

\section{Akupresur}

Dilihat dari titik akupressur, diantara 4 (empat) area yang dilakukan akupressur prosentase terkecil kelancaran produksi ASI ada pada area kaki, tercatat dihari ketiga peningkatan kelancaran hanya $24 \%$, sedangkan pada area yang lain (tangan, leher dan punggung) meningkat diatas 30 $\%$. Hal ini disebabkan karena pada kaki akupressur dilakukan hanya pada 1 (satu) kaki dengan waktu 3 (tiga) menit dan merupakan titik terjauh dari kelenjar alveoli payudara, sedangkan pada area yang lain dilakukan penekanan pada 3 (tiga) titik dengan lama waktu penekanan adalah 9 (sembilan) - 21 (dua puluh satu) menit dan lokasi relatif dekat dengan kelenjar alveoli payudara. Frekwensi akupressur yang dilakukan pada setiap titik adalah sama yaitu pada saat perawat datang dan pada saat perawat hendak pulang dalam waktu 3 (tiga) putaran shif kerja yaitu pagi, sore dan malam.

Tampak pada hasil penelitian lamanya waktu penekanan juga berpengaruh terhadap kelancaran produksi ASI, sesuai dengan tulisan Mahmud, (2011) yang menulis bahwa akupresssur dilakukan dalam waktu 5 menit.

\section{Kecukupan ASI}

Gambaran hasil kecukupan ASI bervariasi diantara 4 (empat) area titik akupressur. Hasil ini dipengaruhi oleh faktor-faktor tertentu diantaranya adalah faktor ibu.

Pada hari 1 (pertama), kecukupan ASI terkecil adalah pada kaki dan tangan (O \%) sedangkan yang terbesar ada di leher dan punggung (35 \%). Hari ke-2 (dua) terjadi peningkatan kecukupan ASI $8 \%$ - $34 \%$ dan pada hari ke-3 (tiga) terjadi peningkatan kecukupan ASI hampir 2 (dua) kali lipat yaitu terjadi peningkatan 16 $\%-42 \%$.

Analogi berfikir semakin lancar produksi ASI, maka akan terjadi kecukupan ASI pada bayi setelah menyusu pada ibunya, namun tidak demikian pada penelitian ini. Kecukupan ASI pada bayi bervariasi, disebabkan karena faktor ibu. Ibu adalah ibu yang melahirkan bayi 
melalui tindakan operasi Seccio caesarrea (SC) yang berefek timbulnya rasa nyeri akibat perlukaan operasi, sedangkan rangsang nyeri berbeda-beda antar individu, ditambah lagi efek narcose yang diberikan sebelum operasi yang berfungsi mematikan rasa seperti rasa nyeri dan rasa nyeri ini akan timbul setelah efek narcose habis.

Astuti (2015) menyebutkan faktor yang mempengaruhi Kecukupan ASI pada bayi yang berasal dari ibu adalah status kesehatan ibu seperti rasa nyeri dan cemas, sedangkan Nichole (2005) menyebutkan bahwa proses melahirkan dengan SC akan menimbulkan rasa cemas dan akan kesulitan dalam menyusui bayinya karena adanya lukan dan rasa nyeri, sehingga ibu merasa tidak berdaya.

\section{Pengaruh Relaksasi Aroma Terapi Rose dan Akuppressur Pada Tangan Terhadap Kecukupan ASI}

Hasilnya adalah $R$ Square $=46,8 \%$ : artinya aroma terapi rose dan akupressur di tangan secara bersama-sama mempengaruhi 46,8 \% kecukupan ASI dengan nilai signifikansi 0,00 yaitu $(0,00<0,05)$.

Perlakuan pada penelitian ini adalah melakukan relaksasi aroma terapi rose dengan metode inhalasi kemudian akupressur selama 9 menit.

Titik pada tangan yang dilakukan akupressur adalah titik produksi ASI, dilakukan di 3 (tiga) area yaitu pada punggung tangan : titik Si 1 yang terletak dibatas buku jari pertama jari kelingking dan titik Li 4 yang terletak pada bagian bawah antara ibu jari dan jari telunjuk kemudian pada bagian telapak tangan yaitu titik Pc 6 yang terletak dibawah telapak tangan tepat ditengah-tengah pergelangan tangan. Titik akupressur di tangan mempengaruhi sekresi kelenjar payudara ibu yaitu kelenjar alveoli.

Menurut Roesli tahun 2000 dalam Astuti (2015) bahwa produksi ASI berasal dari hasil sekresi kelenjar payudara.

Akupressur adalah menekan titik simpul saraf pada kelenjar produksi ASI yang mempengaruhi stimulan pembuluh darah dari vaso konstriksi menjadi vasodilatasi sehingga terjadi pelebaran aliran produksi ASI, di satukan dengan relaksasi aroma rose yang mengandung farnesol dan collagen yang bersifat vasodilator, mengelastisitas kulit, meningkatkan metabolisme tubuh dan merangsang generasi sel (Blogspot.co.id, 2016), selain itu titik pada tangan secara aktif selalu melakukan gerakan-gerakan sehingga menambah aktif vasodilatasi pembuluh darah.

\section{Pengaruh Relaksasi Aroma Terapi Rose dan Akuppressur Pada Kaki Terhadap Kecukupan ASI}

Hasilnya adalah $R$ Square $=38,0 \%$ : artinya aroma terapi rose dan akupressur di kaki secara bersama-sama mempengaruhi $38 \%$ kecukupan ASI dengan nilai signifikansi 0,00 yaitu $(0,00<0,05)$.

Pada titik akupressur dikaki (titik ST 36) dilakukan pada satu titik dikaki yaitu pada kaki kanan selama 3 (tiga) menit, juga bersifat menekan simpul saraf yang mempengaruhi rangsangan produksi ASI, namun hasil penelitian mencatat hasil rangsangan di kaki pengaruhnya sangat kecil jika dibandingkan dengan titik akupressur lainnya. Hal ini disebabkan pendeknya waktu menekan, kaki relatif immobil jika dibandingkan dengan tangan dan jauh dari lokasi kelenjar payudara, sehingga perangsangan menjadi lambat. Pernyataan Mahmud (2011) Akupressur dilakukan minimal 5 menit.

Titik ST 36 adalah salah satu titik yang merangsang produksi ASI, bersifat vasodilator dipadukan dengan aroma terapi rose yang diberikan dengan metode inhalasi. Rose mengandung zat relaksator yaitu Asam tartat (aspartat) yang merangsang saraf, rasa nyaman (menyegarkan), meningkatkan semangat dan gairah hidup dengan mekanisme kerja merangsang struktur otak dan sistem saraf.

Keadaan ini mendukung pernyataan Nichole (2005) bahwa perasaan relaks akan mampu merangsang produksi ASI dan Muchtaridi (2015) menyatakan bahwa relaksasi aroma terapi merupakan alternatif 
pengobatan yang bersifat ilmiah, membantu mempengaruhi proses fisiologis tubuh diantaranya adalah mempengaruhi struktur otak dan sistem saraf pusat.

\section{Pengaruh Relaksasi Aroma Terapi Rose dan Akuppressur Pada Leher dan Punggung Terhadap Kecukupan ASI}

Hasilnya adalah $R$ Square $=79,8 \%$ : artinya aroma terapi rose dan akupressur di leher dan punggung secara bersamasama mempengaruhi 79,8 \% kecukupan ASI dengan nilai signifikansi 0,00 yaitu $(0,00<0,05)$.

Titik yang dilakukan akupressur di leher (SP 7) dan punggung berpasangan kiri dan kanan adalah titik CV7 adalah titik oksitocin, mempengaruhi $>50 \%$ produksi ASI yaitu $80 \%$.

Letak titik oksitocin dekat dengan kelenjar sekresi payudara yaitu kelenjar alveoli, juga sering bergerak karena pengaruh gerakan ibu saat merubah posisi kepala. Menekan kedua titik ini bertujuan merangsang kelenjar oksitocin untuk memproduksi hormon aksitocin yang berguna membuat aliran ASI menjadi lancar, sehingga memotivasi bayi untuk menyusu ketika disusukan oleh ibunya.

Berdasarkan buku terbitan (Kemenkes RI, 2015) ialah rangsang oksitocin dengan melakukan akupressur pada titik-titiknya akan membantu merangsang aliran ASI dari payudara.

\section{Pengaruh Relaksasi Aroma Terapi Rose dan Akuppressur Pada tangan, kaki, Leher dan Punggung Terhadap Kecukupan ASI}

Hasilnya adalah $R$ Square $=100 \%$ : artinya aroma terapi rose dan akupressur di leher dan punggung secara bersamasama mempengaruhi $100 \%$ kecukupan ASI dengan nilai signifikansi 0,00 yaitu $(0,00<0,05)$.

Pada titik ini, peneliti melakukan akupressur dengan cara merangsang semua titik yaitu titik produksi ASI dan titik oksitocin. Menekan selama 3-21 menit pada titik yang membantu pengeluaran ASI yaitu titik produksi ASI bertujuan sebagai vasodilator kelenjar sekresi payudara dan titik oksitocin bertujuan merangsang produksi hormon oksitocin yang berfungsi melencarkan aliran ASI. Muchtaridi (2015) menyatakan bahwa aroma terapi akan mempengaruhi proses fisiologis tubuh dan kemenkes RI (2015) menyatakan bahwa akupressur pada titik produksi ASI dan titik oksitocin akan merangsang payudara memproduksi ASI.

Hasil penelitian yang telah diuraikan di atas, mendukung hasil penelitian yang telah dilakukan sebelumnya oleh Cholifah (2014), Vidayanti (2015) dan Wijayanti Lilis (2014). Ke-3 (tiga) penelitian ini menyatakan ada perbedaan antara kelompok kontrol dengan kelompok perlakuan pada kecukupan ASI bayi yang dilahirkan melalui proses persalinan operasi SC.

Penelitian Cholifah merupakan penelitian dengan melakukan tehnik akupressur pada titik produksi ASI. Penelitian Cholifah di tahun 2014 sama dengan penelitian ini yaitu melakukan akupressur pada titik produksi ASI di tangan (Si 1, Li 4, Pc 6) dan di kaki (ST 36) dengan hasil yang mendukung hasil dari penelitian Cholifah (2014). Perbedaan penelitian adalah pada kelompok responden, kalau penelitian Cholifah (2014) menggunakan dua kelompok yaitu kelompok kontrol dan kelompok perlakuan dengan tujuan mencari perbedaan kecukupan ASI antara bayi pada kelompok kontrol dan kelompok perlakuan, sedangkan penelitian ini adalah penelitian dengan 1 (satu) kelompok tanpa kelompok kontrol. Penelitian ini menggunakan desain penelitian One Group time Series yang melakukan pengamatan terhadap pengaruh relaksasi aroma terapi rose dan akupresssur pada titik produksi ASI dan titik oksitocin dengan kecukupan ASI, pada penelitia ini mengamati perlakuan pada variabel bebas dan pengaruhnya diamati pada variabel terikat tanpa ada kelompok kontrol.

Persamaan penelitian Cholifah (2014) dengan penelitian ini (Susilawati fepi ; Halim abdul, 2017) adalah pada kelompok responden sama-sama dilakukan 
pada ibu dengan proses melahirkan melalui operasi SC.

Penelitian Vidayanti (2015) dan Wijayanti Lilis (2014) adalah penelitian dengan melakukan akupressur pada titik oksitocin, Vidayanti menggunakan minyak lavender saat melakukan akupressur, namun tidak dengan relaksasi metode inhalasi, sedangkan Wijayanti Lilis hanya melakukan pemijatan pada titik oksitocin. Penelitian ini juga melakukan akupressur pada titik oksitocin yaitu pada leher (PV 7) dan punggung (CV 7), dengan hasil mendukung penelitian yang telah dilakukan terdahulu, namun terdapat perbedaan pada kelompok responden. Ke-2 (dua) peneliti terdahulu ini bertjuan mencari perbedaan kecukupan ASI, mengunakan kelompok kontrol dan kelompok perlakuan, dengan hasil ada perbedaan kecukupan ASI antara kelompok kontrol dan kelompok perlakuan. Penelitian ini (Susilawati Fepi ; Halim abdul, 2017) merupakan penelitian yang memadukan antara akupressur pada titik produksi ASI dan titik oksitocin dengan relaksasi metode inhalasi aroma rose. Hasilnya adalah relaksasi aroma terapi rose dan akupressur secara bersamasama $100 \%$ mempengaruhi kecukupan ASI (khusus pada titik oksitocin mempengaruhi kecukupan ASI sebanyak $80 \%)$.

Peneliti sebelumnya yaitu Cholifah (2014), Vidayanti (2015) dan Wijayanti Lilis (2014) melakukan perlakuan hanya dengan akupressur pada titik produksi ASI dan titik oksitocin. Kelebihan penelitian yang dilakukan ini adalah memberikan 2 (dua) perlakuan yaitu relaksasi aroma terapi rose dan akupressur pada titik produksi ASI dan oksitocin.

Data yang diperoleh dari hasil penelitian ini, terhadap kelancaran produksi ASI menggunakan perlakuan relaksasi aroma terapi rose dan akupressur (titik produksi ASI dan titik oksitocin) yaitu:

1. Hari Pertama belum mengeluarkan ASI, yang keluar adalah colostrum yang diamati dengan cara menekan pangkal puting susu ibu, selain itu pengaruh hari pertama pada ibu adalah tercipta perasaan nyaman, timbul sensasi (rasa0 perubahan pada kelenjar payudara yang merupakan pengaruh dari aroma terapi rose.

2. Hari ke-2 (dua). ASI yang keluar bervariasi antara responden. ASI sudah keluar lebih banyak dan lebih lancar jika dibandingkan hari pertama dan sudah bisa diberikan pada bayi.

3. Hari ke-3 (tiga). Produksi ASI semakin lancar. Bayi sudah mulai disusukan dan terdapat tanda kecukupan ASI pada bayi, walaupun ada pengaruh faktorfaktor tentu.

Kondisi di atas, tidak sesuai dengan pernyataan Astuti (2015) dalam buku yang ditulisnya bahwa “... produksi ASI terstimulasi pada hari ke-7 (tujuh), sedangkan pada hari-hari diminggu pertama merupakan masa pemulihan otototot setelah melahirkan", ternyata dengan melakukan relaksasi aroma terapi rose dan akupressur pada titik produksi ASI dan titik oksitocin, produksi ASI dapat terjadi pada hari ke-3 (tiga). Penelitian ini hasilnya sesuai dengan pernyataan Muchtaridi (2015) bahwa akupressur akan berpengaruh pada fungsi fisiologis tubuh yaitu mempengaruhi struktur otak dan sistem saraf pusat, sedangkan Siregar (2012) dan Sukanta (2014) menganjurkan berbagai cara melakukan akupressur pada titik produksi ASI dan titik oksitocin yang bermanfaat untuk meningkatkan daya tahan tubuh dan mengatasi rasa kekakuan (Vaso konstriksi). Efek akupressur adalah merubah vaso konstriksi menjadi vaso dilatasi.

Pada ibu post partum dengan tindakan SC banyak faktor yang mempengaruhi produksi ASI diantaranya adalah rasa nyeri dan kecemasan akibat operasi sehingga berpengaruh pada proses menyusui, walaupun ASI sudah keluar, adakalanya karena nyeri ibu tetap tidak menyusui bayinya dan memberikan susu formula.

Astuti (2015) dan Kemenkes RI (2015) menyatakan bahwa produksi ASI dipengaruhi oleh rasa nyeri dan kecemasan 
ibu, sehingga banyak ibu yang tidak mau menyusui bayinya.

Berdasarkan hasil penelitian, ASI akan keluar pada hari ke-7 (tujuh) dapat terstimulasi pada hari ke-3 (tiga) dan ketidak lancaran produksi ASI dapat diatasi dengan cara melakukan tehnik relaksasi metode inhalasi dengan aroma terapi rose di padukan dengan melakukan akupressur pada titik produksi ASI dan titik oksitocin selama 9 menit, karena tindakan ini akan mempengaruhi proses fisiologis tubuh yaitu mempengaruhi struktur otak dan susunan saraf pusat dengan memproduksi hormon oksitocin melalui aktifasi kelenjar sekresi payudara untuk mengeluarkan ASI.

Kecukupan ASI pada bayi, dari hasil penelitian yang diobservasi menggunakan lembar observasi adalah :

1. Hari Pertama, belum terdapat tanda kecukupan ASI, namun demikian bayi sudah mulai disusukan karena ASI yang keluar adalah Colostrum yang berguna untuk peningkatan imunitas bayi.

2. Hari ke-2 (dua). ASI keluar sudah mulai lancar. Tanda kecukupan ASI tercapai sebanyak $67 \%$. Tanda kecukupan ASI berbeda-beda antar responden karena dipengaruhi oleh faktorfaktor tertentu, ada bayi yang sudah cukup pemenuhan kebutuhan ASInya sehingga tidak perlu diberikan susu formula, namun ada ibu yang menyusukan bayinya dengan tetap memberikan susu formula.

3. Hari ke-3 (tiga). Kecukupan ASI meningkat menjadi $71 \%$, walaupun masih ada juga ibu yang menyusui bayinya dengan menanmbahkan susu formula.

Kecukupan Asi berbeda-beda, yang sudah terpenuhi mulai hari ke-2 (dua) dan meningkat hari ke-3 (tiga) dan akan semakin meningkat pada hari-hari berikutnya. Keadaan yang berbeda-beda antar responden dipengaruhi oleh faktorfaktor tertentu yang umunya berasal dari faktor ibu, sedangkan yang berasal dari faktor bayi adalah bila bayi dalam keadaan infeksi sehingga memerlukan tindakan khusus. Faktor yang mempengaruhi kecukupan ASI yang berasal dari ibu, yang diperoleh dari hasil penelitian adalah:

1. Kelelahan yang disebabkan oleh proses pra hospital yang mempengaruhi hingga proses pasca operasi.

2. Luka sayatan membengkak, dengan proses penyembuhan luka terhambat karena ada tanda infeksi seperti kemerahan, luka basah.

3. Nyeri yang berlebihan akibat luka operasi

4. Kecemasan terhadap diri karena luka operasi dan nyeri.

Kondisi ini sesuai dengan pernyataan Astuti (2015) yang menyatakan bahwa ada beberapa faktor yang mempengaruhi produksi ASI diantaranya adalah Nyeri, cemas dan kesehatan ibu.

Selama proses penelitian, Perawatan di lokasi penelitian tidak melakukan upaya untuk merangsang pengeluaran ASI, yang dilakukan hanyalah tindakan pengobatan berdasarkan kolaborasi dengan dokter, seperti pengobatan luka operasi dan mengatasi rasa nyeri.

\section{KESIMPULAN}

Hasil penelitian menyimpulkan bahwa gambaran pengaruh aroma terapi rose dan akupressur terhadap kelancaran produksi ASI pada ibu menyusui Post SC yang di rawat ialah pada hari pertama yang keluar hanya colustrum, hari ke-2 (dua) terjadi peningkatan kelancaran ASI antara $8 \%$ - $38 \%$ dan semakin meningkat pada hari ke-3 (tiga), peningkatan kelancaran ASI pada hari ke-3 (tiga) antara $34 \%-70$ $\%$.

Selanjutnya diperoleh gambaran kecukupan ASI pada bayi usia 1-3 hari sesudah dilakukan relaksasi aroma rose dan akupressur adalah pada hari pertama, kecukupan ASI terkecil pada kaki dan tangan $(\mathrm{O} \%)$ sedangkan yang terbesar ada di leher dan punggung (35\%). Hari ke-2 (dua) terjadi peningkatan kecukupan ASI $8 \%$ - $34 \%$ dan pada hari ke-3 (tiga) terjadi peningkatan kecukupan ASI hampir 2 (dua) kali lipat yaitu terjadi peningkatan $16 \%-42 \%$. 
Berdasarkan titi akupresur diperoleh kesimpulan bahwa pengaruh relaksasi aroma terapi rose dan akupressur di tangan secara bersama-sama mempengaruhi 46,8\% kecukupan ASI bayi usia 1-3 hari. Sedangkan pengaruh relaksasi aroma terapi rose dan akupressur di kaki secara bersama-sama mempengaruhi $38 \%$ kecukupan ASI bayi usia 1-3 hari. Selanjutnya pengaruh relaksasi aroma terapi rose dan akupressur di leher dan punggung secara bersama-sama mempengaruhi 79,8\% kecukupan ASI bayi umur 1-3 hari dan pengaruh relaksasi aroma terapi rose dan akupressur di tangan, kaki, leher dan punggung pada ibu menyusui post SC yakni secara bersamasama mempengaruhi 100 kecukupan ASI bayi usia 1-3 hari.

Berdasarkan hasil tersebut penulis menyarankan agar aroma terapi rose dan akupresur dapat diaplikasikan dalam bentuk pemberian tindakan keperawatan pada ibu melahirkan sehingga bisa meningkatkan kualitas produksi ASI dan kecukupan ASI bagi bayinya.

\section{DAFTAR PUSTAKA}

Astuti. 2015. Buku Ajar Asuhan Kebidanan Ibu 1. Rohima Press : Jogjakarta

-------------- Asuhan Kebidanan Nifas dan Menyusui. Jakarta : Erlangga

Blog spot. 2016. Khasiat Mawar. Khasiatq.blogspot.co.id/20016/16/Kh asiat Mawar untuk kesehatan.html
Cholifah. 2014. akupresure pada ibu menyusui meningkatkan kecukupan asupan ASI bayi di Kecamatan Mungkid. https://ppnijateng.org/../keperawatan Maternitas_Vol-3-No-2.41

Dinkes Prop Lampung. 2015. Profil Kesehatan Provinsi Lampung 2015

Kemenkes. 2015. Profil Kesehatan Indonesia 2015. Jakarta: Kemenkes RI.

Mahmud, D. AR, 2011. Buku Pintar Sehat Seumur Hidup Melalui Tiga Terapi Alternatif. Yayasan Media Kesehatan Alternatif. Jakarta

Muchtaridi \& Mulyono. 2015. Aroma Therapi : Tinjauan Aspek Kimia Medisinal. Graha ilmu : Jogjakarta

Nichole. 2005. Panduan Menyusui. Jakarta : Prestasi Pustakaria

Vidayanti. 2015. Pengaruh pijat punggung menggunakan minyak esensial lavender terhadap produksi ASI pasca bedah sesar di RSUD Panembahan Senopati Bantul. Uppm, poltekkes kemenkes semarang.

Journal.respati.ac.id/index.php/medic a/article/view/199

Siregar, abidinsyah. 2012. Orientasi akupresur bagi petugas puskesmas.

Sukanta, Putu Oka. 2014. Pijat akupresur untuk kesehatan. Jakarta : Promplus.

Wijayanti Lilis. 2015. pengaruh pijat oksitosin terhadap produksi ASI pada ibu post partum di Puskesmas Mergangsan Yogyakarta. Apc.unisa yogya.ac.id/1076/1/naskah\%20publi kasi.pdf 